\title{
DNA barcodes for soil animal taxonomy
}

\author{
Rodolphe Rougerie ${ }^{(1)}$, Thibaud Decaëns ${ }^{(2)}$, Louis Deharveng ${ }^{(3)}$, David Porco(1), Sam W. James ${ }^{(4)}$, \\ Chih-Han Chang ${ }^{(5)}$, Benoit Richard(2), Mikhail Potapov ${ }^{(6)}$, Yayuk Suhardjono ${ }^{(7)}$ and Paul D.N. Hebert ${ }^{(1)}$
}

\begin{abstract}
(1)University of Guelph, Biodiversity Institute of Ontario, 579 Gordon Street, Guelph, Ontario, N1G 2W1, Canada. E-mail: rrougeri@uoguelph.ca, dporco@uoguelph.ca, phebert@uoguelph.ca(2)Université de Rouen, Laboratoire d'Ecologie/UPRES-EA 1293 ECODIV, UFR Sciences et Techniques, F-76821 Mont Saint Aignan cedex, France. E-mail: thibaud.decaens@univ-rouen.fr, benoit.richard@etu.univ-rouen.fr (3)Muséum National d'Histoire Naturelle, Département Origine, Structure et Evolution de la Biodiversité, UMR5202 CNRS/MNHN, CP 50, 45 rue Buffon, 75005 Paris, France. E-mail: deharven@mnhn.fr (4)Kansas University, Natural History Museum and Biodiversity Research Center, 1345 Jayhawk Drive, Lawrence, KS 66045, USA. E-mail: sjames@ku.edu ${ }^{(5)}$ National Taiwan University, Institute of Zoology and Department of Life Science, No. 1, Roosevelt Road, Section 4, Taipei 106, Taiwan. E-mail: r91225025@ntu.edu.tw ${ }^{(6)}$ Moscow State Pedagogical University, Zoology Department, Kibalchicha 6 B.5, Moscow 129278, Russia. E-mail: mpnk@orc.ru (7)Museum Zoologicum Bogoriense, RC-Biology, Cibinong Science Center LIPI, JI, Raya Jakarta-Bogor, Km 46, Cibinong 16911, Indonesia. E-mail: yayukrs@indo.net.id
\end{abstract}

Abstract - The biodiversity of soil communities remains very poorly known and understood. Soil biological sciences are strongly affected by the taxonomic crisis, and most groups of animals in that biota suffer from a strong taxonomic impediment. The objective of this work was to investigate how DNA barcoding - a novel method using a microgenomic tag for species identification and discrimination - permits better evaluation of the taxonomy of soil biota. A total of 1,152 barcode sequences were analyzed for two major groups of animals, collembolans and earthworms, which presented broad taxonomic and geographic sampling. Besides strongly reflecting the taxonomic impediment for both groups, with a large number of species-level divergent lineages remaining unnamed so far, the results also highlight a high level (15\%) of cryptic diversity within known species of both earthworms and collembolans. These results are supportive of recent local studies using a similar approach. Within an impeded taxonomic system for soil animals, DNA-assisted identification tools can facilitate and improve biodiversity exploration and description. DNA-barcoding campaigns are rapidly developing in soil animals and the community of soil biologists is urged to embrace these methods.

Index terms: Collembola, cryptic diversity, DNA barcoding, Oligochaeta, species identification, taxonomic crisis, taxonomic impediment.

\section{Código de barras de DNA para a taxonomia de animais do solo}

Resumo - A biodiversidade das comunidades do solo continua muito pouco conhecida e entendida. A biologia do solo é fortemente afetada pela crise taxonômica, e a maior parte dos grupos de animais dessa biota sofre forte impedimento taxonômico. O objetivo deste trabalho foi determinar como o código de barras de DNA - um método novo que usa uma etiqueta microgenômica para identificação e discriminação de espécies permite uma melhor avaliação da taxonomia da biota edáfica. Foram analisadas 1.152 sequências de códigos de barras de dois grupos principais de animais, colêmbolos e minhocas, que apresentaram ampla amostragem taxonômica e geográfica. Além de refletir fortemente o impedimento taxonômico de ambos os grupos, com um grande número de linhagens divergentes no nível da espécie que ainda não está descrita, os resultados também destacam um alto (15\%) nível de diversidade críptica dentro de espécies conhecidas de minhocas e colêmbolos. Esses resultados apóiam estudos locais recentes que usaram métodos similares. Considerando as dificuldades taxonômicas enfrentadas para identificar os animais de solo, ferramentas de identificação usando DNA podem facilitar e melhorar a exploração da biodiversidade e a sua descrição. As campanhas de código de barras de DNA estão se desenvolvendo rapidamente com animais do solo, e a comunidade de biólogos é incitada a adotar esses métodos.

Termos para indexação: Collembola, diversidade críptica, código de barras de DNA, Oligochaeta, identificação de espécies, crise taxonômica, impedimento taxonômico.

\section{Introduction}

Soil animal communities comprise one of the largest biodiversity reservoirs in terrestrial biota(Decaëns etal., 2006). They are part of highly complex ecosystems, the organization and composition of which remain far from being understood or even approximated from finest to broadest scales. While that state of the art has been repeatedly stressed in the literature during the past two decades (André et al., 1994, 2001), Dance (2008) 
reports that the situation in the field is quite unchanged. Soil is populated by probably millions of species whose discrimination remains an unfaced challenge, whether dealing with microbial diversity (Roesch et al., 2007; Fulthorpe et al., 2008) or with organisms of the micro to megafauna (Decaëns et al., 2008), with likely some degree of correlation between knowledge and animal size (Decaëns et al., 2006; Stork et al., 2008).

Genetic data have been used in different groups as a complement or a surrogate (DNA taxonomy, as applied in protists) to traditional approaches, and bring valuable and often decisive insights at intra to interspecific levels (Frati et al., 2000; Scheffer, 2000). With the democratization of access to molecular techniques, such alternative or complimentary approaches clearly open new perspectives for soil biologists, whatever the group studied (Carapelli et al., 1995, 2005; Frati et al., 2000; Pop et al., 2003; Heethoff et al., 2004; Hogg \& Hebert, 2004; Burkhardt \& Filser, 2005; Chang \& Chen, 2005; Pérez-Losada et al., 2005; Bhadury et al., 2006; Heethoff et al., 2007; Huang et al., 2007; Cameron et al., 2008; King et al., 2008; Chang et al., 2009). DNA barcoding uses a single standard genetic marker for species identification (Hebert et al., 2003). This technique was proposed as a promising approach (Decaëns et al., 2008) to address the soil animals' taxonomic impediment at an unrivaled pace and an improved level of resolution.

In this paper, a synthetic review of DNA barcoding in the context of the taxonomic crisis is provided, and preliminary results that assess the efficiency and reliability of the DNA barcoding approach are presented to document and explore biodiversity within two groups of soil animals: earthworms, as part of the soil megafauna, broadly used models and supposedly relatively well known taxonomically; and collembolans, as part of the mesofauna, an omnipresent group of organisms suffering a strong taxonomic impediment. Although these are early days for large-scale DNA-barcoding campaigns, the aim of targeting these two groups of soil animals is to estimate the global applicability of the method and assess its potential for transcending the final frontier of soil biodiversity.

\section{The taxonomy crisis}

Taxonomy is a science in crisis (Godfray, 2002; Hopkins \& Freckleton, 2002; Wilson, 2003; Agnarsson
\& Kuntner, 2007). Despite its status of "fundamental discipline" (Wilson, 2004) with a cascade of derivative functions, taxonomy is one of the weakest and most underfunded biological disciplines (Wilson, 2003). The few encouraging major initiatives (e.g. the Global Taxonomy Initiative launched after the adoption of the Convention on Biological Diversity - CBD; the National Science Foundation's Partnerships for Enhancing Expertise in Taxonomy - NSF-PEET, USA; the European Distributed Institute of Taxonomy - EDIT; and a number of other biodiversity-oriented projects) are facing a dramatic, so far irreversible, general trend of ever-growing deficit of taxonomists coupled with a strong imbalance between the species diversity of large taxonomic groups and the effective taxonomists for these particular groups (Brown \& Lomolino, 1998). Although the distribution of taxonomic work between the professional and amateur communities is certainly disparate among groups and remains difficult to evaluate, Hopkins (2002) showed that the effectiveness of both communities tends to decrease more dramatically for professional scientists, whose proportion as authors of taxonomic papers also diminishes. An even more critical concern is the legacy of the knowledge and expertise of taxonomists which, after what is frequently a life-time work devoted to a group of organisms, is never fully transmitted to the next generation of either taxonomists or other users of taxonomy. At best, a number of publications, taxonomic descriptions, revisions and identification keys are available - more or less accessible to non-expert users throughout the world - but, as a general rule, it is a large part of a yet unpublished expertise and unique ability to identify species that simply vanish. In addition, the general consideration and understanding of taxonomists' work by the public and policy makers is part of the current crisis: biologists still have to convince and educate about the interest and value of documenting biodiversity, of becoming "bioliterate" (Janzen, 2004; Janzen et al., 2005). Only by doing so can taxonomy remain on the "front seat" of environmental policies (Samper, 2004), evolve as a dynamic field of biological sciences and thus be given the means for its survival and development. Different authors have stressed the need for a mutation, a "renaissance" of the field (Godfray, 2002; Wheeler, 2004; Agnarsson \& Kuntner, 2007). In particular, it has been urged that taxonomists embrace the use of new technologies to ease access to various 
sets of information relevant to taxonomy: taxonomy should move on the web, and its instances and rules should rapidly adapt to new ways of disseminating and producing taxonomic information (Godfray, 2002; Wilson, 2004; International Commission on Zoological Nomenclature, 2008). There exist here, at least in part, solutions that address the expertise legacy issue. Also, by facilitating the work of taxonomists, one could expect acceleration in the pace of biodiversity exploration and description, a crucial point at a time where we may have documented as little as $10 \%$ of our planet's biodiversity during the last 250 years.

\section{About the taxonomic impediment}

The existence of a taxonomic impediment (Godfray, 2002; Samper, 2004; Wheeler et al., 2004) or "taxonomy deficit" (Blaxter, 2004) has been widely acknowledged. It is sometimes mentioned as a characteristic of some groups whose diversity remains in a very large part unknown and as a consequence undescribed. In a broader sense, as stated on the CBD website (Global Taxonomy Initiative, 2009), the taxonomic impediment consists of "the knowledge gaps in our taxonomic system (including those associated with genetic systems), the shortage of trained taxonomists and curators, and the impact these deficiences have on our ability to conserve, use and share the benefits of our biological diversity." The extent of this impediment results in prejudices that are highly diverse and affect us at large. For instance, the choice of model organisms is dramatically unbalanced towards the selection of the best-known taxa. Conservation strategies are frequently driven by the use of umbrella or flagship species as surrogates for a more diverse set of poorly known organisms (Andelman \& Fagan, 2000). According to values in the 2003 IUCN (International Union for Conservation of Nature) Red List of Threatened Species as reported by McNeely (2006), only $768(0.08 \%)$ insect species were evaluated, of which $552(72 \%)$ were considered as threatened, that is only $0.06 \%$ of described species. In birds and mammals, 100 and $98.9 \%$ of the described species were evaluated, and 12 and $24 \%$ were considered threatened, respectively. As palliatives to the taxonomic impediment, higher taxa have also been proposed as surrogates (Mandelik et al., 2007) using coarse taxonomic scales, as well as recourse to parataxonomy and the identification of organisms down to "recognizable taxonomic units", also known as morphospecies or morphotypes (Krell, 2004). Both methods have serious pitfalls (Krell, 2004), unpredictable error rate and hardly reproducible results. Additionally, in groups such as earthworms, which are expected to be relatively taxonomically well known, at least in temperate countries where they are much used in various kinds of soil studies (e.g. ecology, ecotoxicology, bioindicators), a striking and unexpected level of cryptic diversity was recently evidenced through molecular data (King et al., 2008; Richard, 2008) (see also the Results section below). This jeopardizes the correct identification of target organisms and thus the reliability, comparability and reproducibility of results. Bad taxonomy "identification, classification, and nomenclature of organisms without following the appropriate procedures and rules that specialist taxonomists define" - either due to taxonomic shortcuts or overlooked cryptic species, affects soil sciences at large, with a significant and a yet unevaluated risk of error cascades (Bortolus, 2008).

\section{DNA barcoding - a standardized identification method for animals}

A 658-bp fragment of the mitochondrial gene cytochrome c oxidase I (COI) has been proposed as a standard barcode for animal species (Hebert et al., 2003). The principle is that the bimodality of intra and interspecific genetic variations will permit the use of this genetic marker as a tag to group conspecifics together and distinguish them from other taxa. Coupled with a database associating genetic tags with taxon names, this system provides a reliable and straightforward identification of an unknown specimen (Figure 1). The advantages are numerous: 1, it is a testable and reproducible system, as a link between any barcode and a voucher specimen is maintained; 2 , it is fast (the sequencing process from tissue sampling to sequence upload in the database currently approximates seven hours, but recent advances may reduce that time to two hours only) and accessible in virtually any place where sequencing facilities exist; 3 , it is cheap (the cost per sample in a high-throughput facility approximates 5 USD and is constantly being reduced); 4 , it can be used for the smallest animals for 
which special voucher preservation methods are used (Rowley et al., 2007); 5, it works for any life stage and 6 , for any kind of organic tissue types. The simplicity of the method opens outstanding perspectives, such as the miniaturization of the process likely to become handheld and thus field-accessible within the next few decades; also, direct coupling of DNA barcoding and environmental sequencing through massively parallel pyrosequencing can potentially revolutionize access to local biodiversity information. On the other hand, as one could expect for a newly emergent and fast-developing approach, several potential drawbacks and pitfalls of DNA barcoding have been heavily discussed in literature within the past five years, ranging from methodological and scientific to societal concerns (Will \& Rubinoff, 2004; Rubinoff \& Holland, 2005; Will et al., 2005; Cameron et al., 2006; Meier et al., 2006; Elias et al., 2007; Larson, 2007; Wiemers $\&$ Fiedler, 2007; Song et al., 2008; Trewick, 2008). Of all criticisms, the most redundant is that the use of

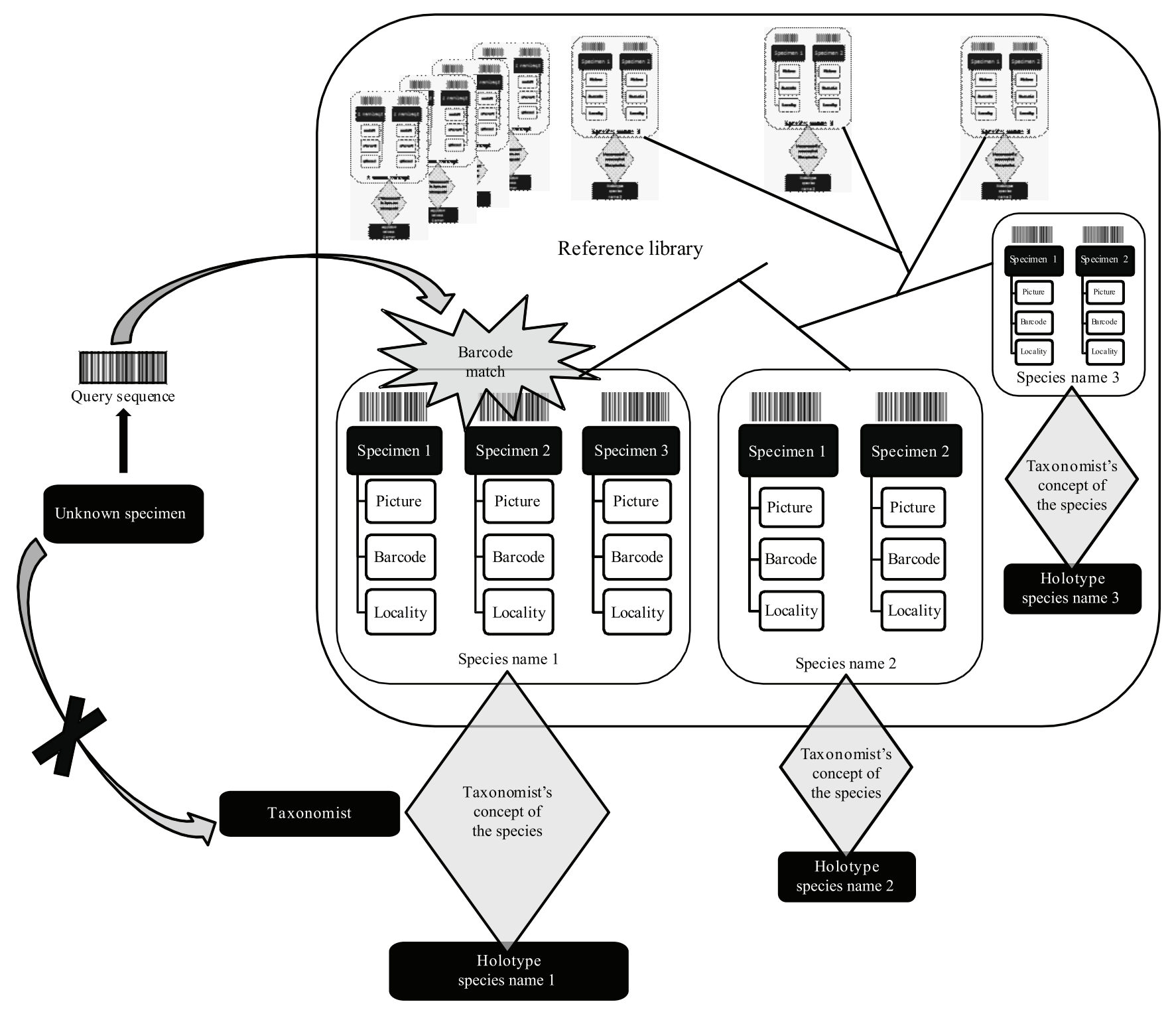

Figure 1. Identification pathway of the query sequence from an unknown specimen by comparison to DNA barcodes present in the reference library. Records in the library are associated to specimen data, including a species name assigned by an expert taxonomist according to his conception of the species by reference to a type specimen usually outside the library. Taxonomists can be relieved from redundant standard identification of unknown specimens. 
a single mitochondrial marker and an arbitrary level of divergence cannot be used to discriminate species because of potential false negatives (identical DNA sequences can be found in two actually different species if the divergence time was too short for the fixation of substitutions, or because of gene introgression), and potential false positives (individuals belonging to the same species may have highly divergent DNA sequences because of ancestral polymorphism or, again, genetic introgression). To overcome these pitfalls, it has then been repeatedly claimed that DNA barcodes should be used in an integrative framework, that is, associated to other sets of data, such as morphology or additional nuclear genetic marker, as well as ecological, ethological or biogeographical features. Interestingly, such data are almost always intimately associated to DNA barcodes from the very beginning of the construction of the reference library (the Barcode of Life Data Systems - BOLD) (Ratnasingham \& Hebert, 2007) for each record that associates a DNA barcode with a taxon name; indeed taxon names are generally hypotheses based on traditionally used characters and thus represent an "in-kind" integrated data complement summarizing the taxonomic expertise available for a particular specimen. As far as no conflict exists between these two sets of information, DNA barcodes then represent reliable identification tags that can be used without further combination of different sources of evidence. Nevertheless, for groups with a strong taxonomic impediment and no available expertise, DNA barcoding may represent the only available source of discriminating data. It should then be used with the necessary caution caused by the pitfalls of the use of a single marker (King et al., 2008), and Molecular Operational Taxonomic Units (MOTUs) should be preferred - at least provisionally - as surrogates to species in poorly known groups (Blaxter, 2004). Overall, the utility of DNA barcoding for species identification and of DNA barcodes as an additional set of data for alpha-taxonomic works has now been revealed in a broad range of taxonomic groups of vertebrates: birds (Hebert et al., 2004), bats (Clare et al., 2007), mammals (Borisenko et al., 2007; Dalebout et al., 2007); and invertebrates: nematodes (Bhadury et al., 2006); earthworms (Huang et al., 2007; Chang et al., 2009); butterflies (Burns et al., 2008); moths (Decaëns et al., 2008; Vaglia et al., 2008); ants (Fisher \& Smith, 2008); mayflies (Webb et al., 2007); caddisflies (Zhou et al., 2007). Outcomes of these works range from biotic surveys to re-evaluation of species complexes, unveiling of cryptic species, new synonyms, etc.; some include formal taxonomic acts (Webb et al., 2007; Burns et al., 2008; Decaëns et al., 2008; Fisher \& Smith, 2008; Vaglia et al., 2008) based on combined evidence from genetic and traditional approaches.

\section{Building the reference library}

Although DNA barcoding studies flourish throughout the world, the results are collectively compiled in a central integrative bioinformatics platform BOLD (Barcode of Life Data Systems, 2009) - that supports all phases of the analytical pathway, from specimen collection to tightly validated barcode library (Ratnasingham \& Hebert, 2007), and can also accommodate externally produced sequences, either through direct submission or regular incorporation of GenBank sequences. The key role of taxonomists in the assemblage and curation of the reference library is strongly stressed here, and taxonomists are encouraged to participate in it. Taxonomists have a unique ability to scrutinize the results of the barcode analyses for their group of interest and, when necessary, to ensure their integration within the classical workflow of new species descriptions and taxonomic revisions (Fisher \& Smith, 2008; Vaglia et al., 2008). Such association enables reliable identification through DNA barcodes by associating this genetic tag with its homologue in the library and with the attached taxonomic hypotheses referring to a species concept and, more practically, to a name incarnated by the type specimen (Figure 1). Quite interestingly, in such framework the DNA sequences represent surrogates to the taxonomic expertise and will ensure the legacy of the integrated expertise independently of further input from taxonomists. This is viewed as a very significant improvement to counterbalance the dramatic loss of expertise when taxonomists stop their activity. Moreover, this does not question the need to develop taxonomy for all these poorly known groups, and emphasizes the primary role that taxonomists should have in further documenting and describing the large unknown part of our planet's biodiversity. While the use of DNA barcodes will likely reduce the taxonomist standard-specimen identification task, an often redundant one, taxonomists will also benefit from DNA sequences for their revisionary work 
Barcodes (but also possibly other genes, since access to them will be facilitated in having at hand the DNA extracts produced and archived during the barcoding process) represent a new set of characters to address taxonomic issues. They can also be used as a screening tool to detect specimens of special interest, and focus on them for further morphological or ecological investigation.

DNA barcoding for earthworms and collembolans

A large sampling campaign was recently initiated for both collembolans and earthworms in order to further evaluate the potential of DNA barcoding in these groups. The method had already been tested for collembolans in the early time of its development for a limited set of arctic taxa (Hogg \& Hebert, 2004). The results revealed unambiguous and reliable discrimination of species through barcode data. In earthworms, Huang et al. (2007) were the first to envision the broader application of DNA barcoding for species identification and discrimination. Their work was recently completed and further examined through broader taxonomic sampling (Chang et al., 2009), confirming a general pattern of deep interspecific divergences opposed to shallow interspecific variation of the barcode fragment in Southeast Asian species of earthworms. King et al. (2008), though not explicitly referring to DNA barcoding, used the same gene region to uncover a striking level of intraspecific divergence and cryptic diversity among a set of common and well-known species of British lumbricid earthworms. In the following part of this paper, the general pattern of variation of COI barcodes in collembolans and earthworms will be further examined by enlarging both the taxonomic and geographic coverage for these groups.

\section{Materials and Methods}

All the specimens sampled and analyzed are part of the DNA-barcoding campaigns initiated for collembolans and earthworms at the Biodiversity Institute of Ontario. All samples were processed at the Canadian Centre for DNA Barcoding (CCDB). DNA was extracted from small pieces of muscular tissue for earthworms and from whole specimens for collembolans. A specific protocol was developed for the latter, so that voucher specimens could be recollected after the lysis step and thus be used for further morphological examination, if necessary.
DNA extraction followed a routine silica-based 96-well extraction automation protocol (Ivanova et al., 2006). The $658 \mathrm{bp}$ region of COI proposed for use as a DNA barcode (Hebert et al., 2003) was amplified with the M13-tailed primers LCO1490 and HCO2198 (Folmer et al., 1994). PCR amplifications were performed according to the standard PCR reaction protocol used in CCDB (Hajibabaei et al., 2005) and were checked on a 2\% E-gel 96 Agarose (Invitrogen). Unpurified PCR products were bidirectionally sequenced using M13F and M13R primers; sequencing reactions followed CCDB protocols (Hajibabaei et al., 2005), with products subsequently purified using Agencourt CleanSEQ protocol (Agencourt, Beverly, MA, USA). The samples that did not yield sequences after this standard procedure were selectively re-amplified with the primer pairs LepF1/MLepR1 and mLepF1/LepR1 (Hajibabaei et al., 2006) targeting shorter DNA fragments. Sequencing reactions were then conducted using LepF1 and LepR1 primers, producing a unidirectional reading except for the $55 \mathrm{bp}$ overlap between the two fragments. The sequences were managed in SeqScape version 2.1.1 (Applied Biosystems, Foster City, CA, USA) and Sequencher 4.5 (Gene Code Corporation, Ann Arbor, MI, USA) and aligned using BioEdit version 7.0.5.3 (Hall, 1999) and MEGA4 (Tamura et al., 2007). Regularly updated protocols used at the CCDB can be found at: http:// www.dnabarcoding.ca/pa/ge/research/protocols. Distance analyses were performed using MEGA4.

\section{Results and Discussion}

As the objective of this paper is to provide a global overview of how DNA barcodes behave when considered in a taxonomic and geographic sampling broader than what has been reported to date, we do not address in depth the results of our analyses. More detailed studies are in preparation, addressing taxonomic questions more thoroughly and considering additional independent datasets. The 1,152 sequences obtained for both studied groups were analyzed separately; they are deposited in GenBank with the following accession numbers: GU013791 to GU014232, FJ937285, FJ937287, FJ937289, FJ937295 to FJ937300, FJ937308 and FJ937315 to FJ937319 for earthworms, and GQ373428 to GQ374122 for Collembolans. In earthworms, a total of 457 sequences were included in the analysis, representing 49 genera within 8 families 
(Figure 2). The geographic coverage includes North America (USA), South America (Brazil, Paraguay), the Caribbean islands, Europe (Andorra, Cyprus, France, Hungary, Romania, Spain), the Middle East (Israel), Southeast Asia (Thailand, Philippines), and Australia. The dataset encompasses a number of unidentified species (mostly those samples from the Philippines and
Brazil) and 87 species identified using morphological characters. The total number of genetic clusters is reported (Table 1) using different threshold levels. It varies from 211 using a $4 \%$ divergence threshold to 192 with a conservative divergence value of $10 \%$. Overall, if considering clusters separated by $10 \%$ or more sequence divergence, then $90.1 \%$ of them reveal

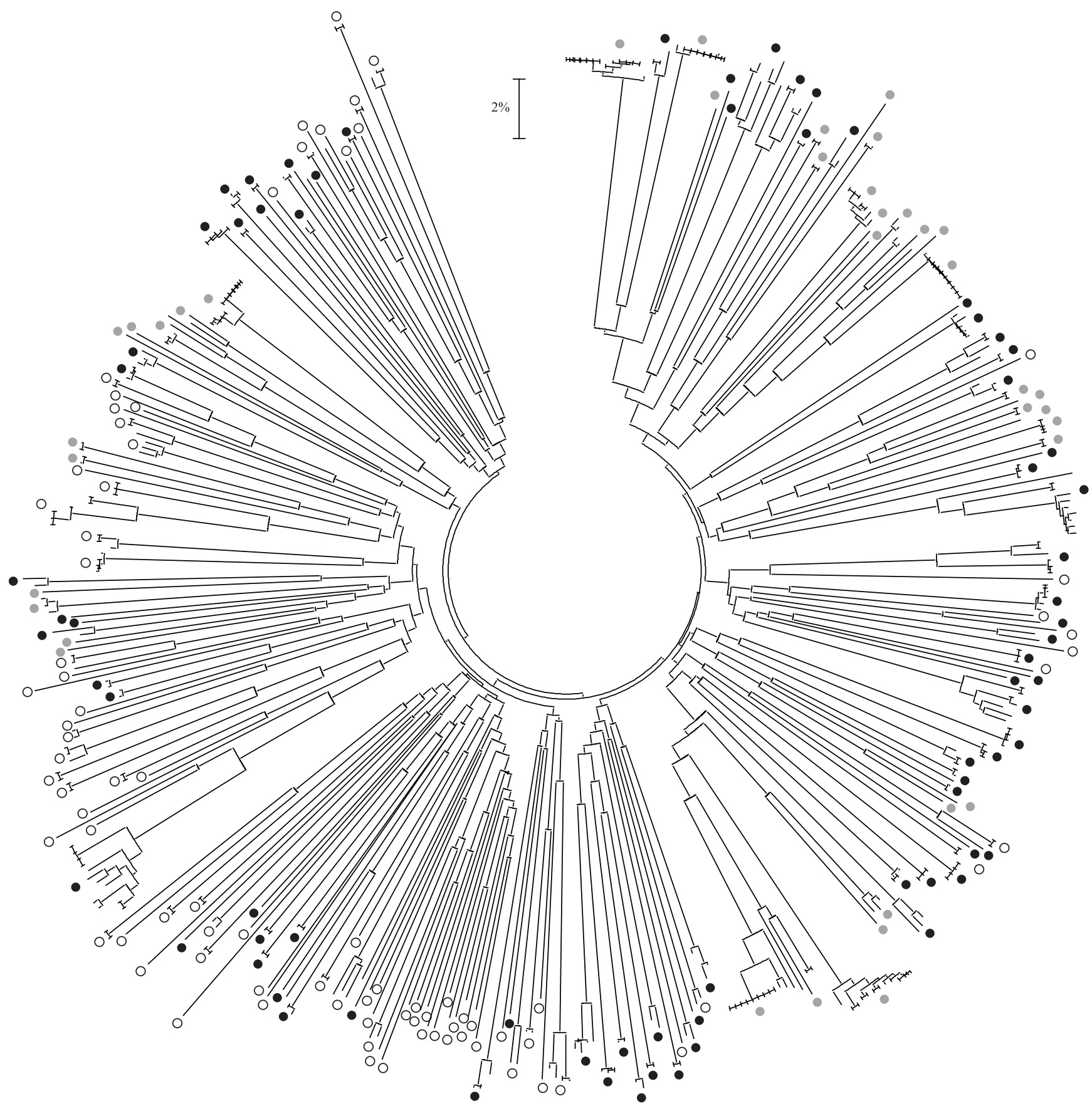

Figure 2. Neighbour-joining tree based on K2P distances from 457 DNA barcode sequences of earthworms. Circles refer to species which are: unidentified (white), identified (black), or identified with intraspecific divergence $>10 \%$ (grey). 
less than $4 \%$ intra-cluster divergence. Also, at that very conservative level of interspecific divergence, 13 of the 87 identified species do split in two or more clusters, revealing potential cases of cryptic diversity. Overall, as apparent from the tree representation of genetic distances (Figure 2), the pattern of DNA barcode variation is very similar to the one reported by Chang et al. (2009) for a more limited regional dataset; indeed, the results obtained clearly show a dominance of deep interspecific divergences and limited intraspecific variability.

In collembolans, 695 sequences belonging to 88 genera in 16 families and including samples from Europe (France, Spain, Slovenia and Romania), North Africa (Algeria), North-America (USA), Southeast Asia (Vietnam, Indonesia), Pacific islands (Vanuatu) and Far East Russia were analyzed. Because of the difficult and poorly known taxonomy of these organisms, only 44 species have been formally identified using morphological characters so far. The genetic clusters are overall very clearly defined (Figure 3). Table 1 summarizes the number of these clusters for different distance thresholds. Interestingly, in the very conservative hypothesis that the 215 observed genetic clusters distinct by $10 \%$ or more from others do represent actual species - though such hypothesis requires additional data to be formally accepted -, then $94.4 \%$ of them have less than $4 \%$ intraspecific divergence. Such pattern, as clearly apparent from the topology of the distance tree (Figure 3), is typical of a bimodal distribution of intra- versus interspecific divergences such as the one also reported in earthworms. On the other hand, out of the 44 identified species, 7 displayed an intraspecific split superior to $10 \%$ and are likely to represent cases of cryptic diversity.

The geographically and taxonomically extended sampling presented in this paper is strongly congruent with the patterns preliminarily documented in earthworms (Huang et al., 2007; King et al., 2008; Chang et al., 2009) and collembolans (Carapelli et al., 1995; Hogg \& Hebert, 2004) at local scales. Both groups show a highly structured variation of the barcode sequences which, in the hypothesis that clusters represent distinct species, indicates a high interspecific barcode divergence opposed to shallow intraspecific variation (Figures 1 and 2). The dataset used appears quite representative of the relative taxonomic impediment of each group. Indeed, 44 collembolan species $(20.4 \%$ of the total number of $>10 \%$ divergent clusters) were identified using only morphology, and the same is valid for 87 earthworms species (45.3\%). Quite interestingly however, DNA barcode analysis revealed a similar level of potential cryptic diversity, with about one for six identified species having one or more divisions exceeding $10 \%$ divergence. At that point, the lack of taxonomic data unfortunately precludes us from safely interpreting these "species-level" divergences and from linking the observed genetic clusters to actual species. Further investigation based on additional independent evidence is needed to address both the exact status of all these unnamed clusters and the striking cryptic diversity revealed within known species. In earthworms, a very close match was found between traditional taxonomic identifications of closely related species and barcode clusters for Taiwanese species, suggesting that these genetic data would reliably identify species and point out cases of cryptic diversity (Chang et al., 2009). Facing that striking pattern of deep "species-level" divergences within British lumbricid earthworms, King et al. (2008) found a global support of AFLP results to all but one case, suggesting that overlooked sibling species would account for a large part of the observed pattern. The use of nuclear genes was shown to be a potentially very efficient complement to mtDNA (Smith et al., 2008), but thus far results remain inconclusive for earthworms (King et al., 2008) and collembolans where it has to be further explored and developed. Much is to be expected, however, from the re-evaluation of morphological features once DNA barcodes have unveiled putative cases of cryptic diversity. For instance, coloration and size, two sets of characters reluctantly used in these groups because of their individual variation, and problems

Table 1. Number of barcode clusters in earthworms and collembolans when considering different divergence thresholds; values in brackets report the percentage of $>10 \%$ divergent clusters showing an internal divergence inferior to the given threshold.

\begin{tabular}{|c|c|c|c|c|}
\hline Groups of soil animals & $4 \%$ & $6 \%$ & $8 \%$ & $10 \%$ \\
\hline Earthworms & $211(90.1 \%)$ & $206(92.7 \%)$ & $198(96.9 \%)$ & 192 \\
\hline Collembolans & $227(94.4 \%)$ & $221(97.2 \%)$ & $219(98.1 \%)$ & 215 \\
\hline
\end{tabular}


related to specimen preservation after collecting may be far more informative than previously assumed (Chang \& Chen, 2005; Chang et al., 2007; Lowe \& Butt, 2008). In earthworms, breeding experiments (Lowe \& Butt, 2008) also represent an excellent alternative to test for lineage isolation and complement genetic data; it may indeed be expected that large genetic divergences would be accompanied by some level of genetic incompatibility. An excellent example of how the combination of genetic data and breeding experiments could successfully complement each other is the evidence brought that
Eisenia fetida and E. andrei are two distinct species (Domínguez et al., 2005; Perez-Losada et al., 2005), thus confirming an earlier congruent conclusion by Jaenike (1982).

Overall, the observed pattern of DNA barcode variation is very favorable to the use of this marker as a species tag, providing a unique and unequaled way of identifying organisms that otherwise require a high and scarcely available level of expertise. However, the very strong taxonomic impediment of both collembolans and earthworms is obvious, and characterized both by

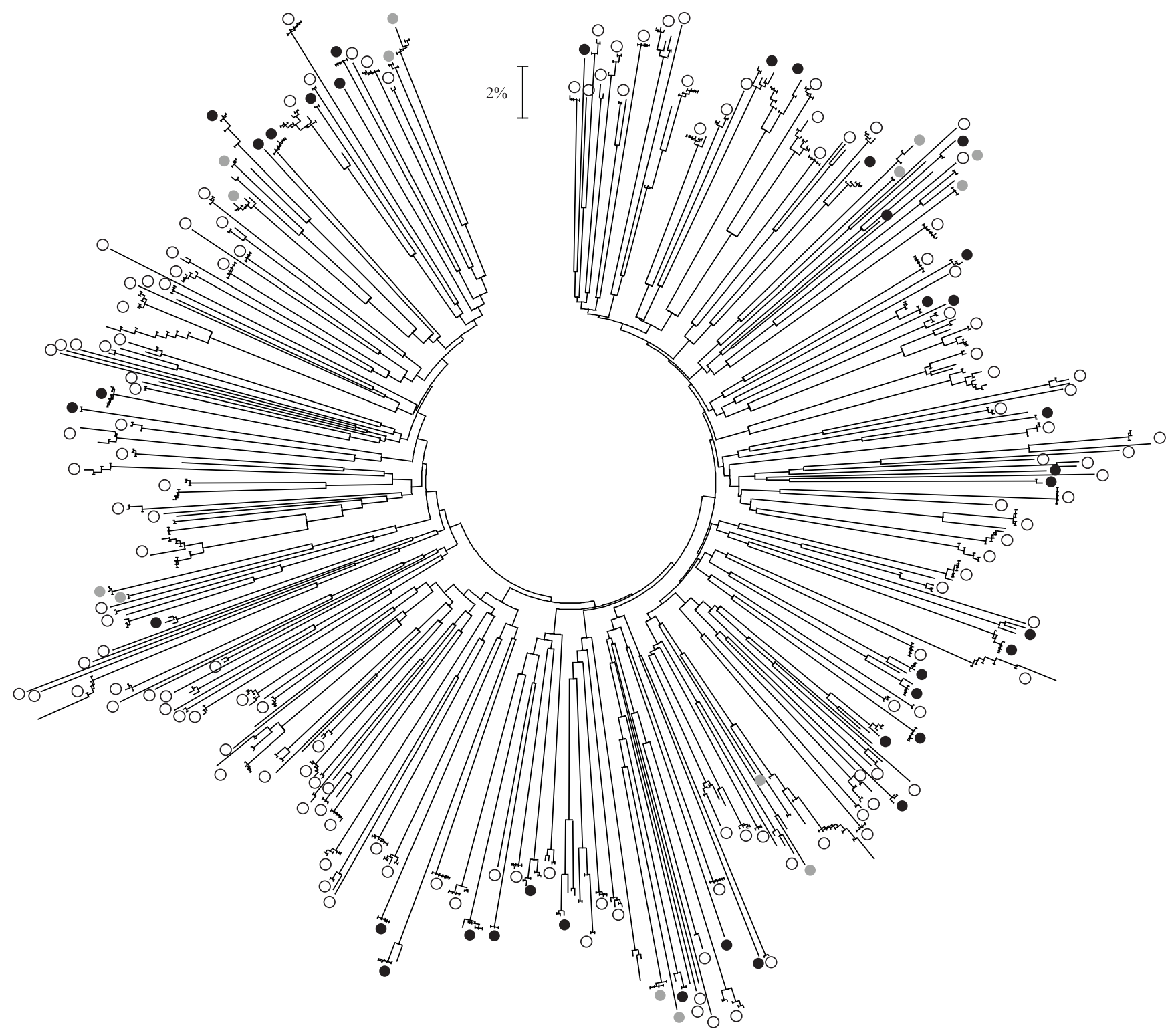

Figure 3. Neighbour-joining tree based on K2P distances from 695 DNA barcode sequences of collembolans. Circles refer to species which are: unidentified (white), identified (black), or identified with intraspecific divergence $>10 \%$ (grey). 
a high level of cryptic diversity within already known species and by a high proportion of taxa that are currently undescribed or need thorough taxonomic scrutiny and investigation to be properly linked to an existing name. Actually, the latter task remains very challenging because of the way type specimens of soil animals are usually preserved. Indeed, types are often very old and preserved (or prepared) using DNA-unfriendly methods (e.g. formaldehyde) that impede their easy use for integrative studies combining genetic and traditional data. Specific protocols and approaches (Herniou et al., 1998; Hajibabaei et al., 2006; Skage \& Schander, 2007; Zimmermann et al., 2008) may prove useful in that prospect of the use of type specimens. In collembolans, the situation is probably worse since most types have been prepared on microscopy slide after clearing preparations that definitely destroy DNA molecules. In any case, the use of DNA to re-evaluate diagnostic morphological characters may allow a robust assignment of recently collected specimens to an ancient type using morphology, or alternatively, in these groups where overlooked cryptic species may be very frequent, the recourse to designation of neotypes for which DNA data are available might be the safest and most efficient way to proceed.

Interestingly, the use of DNA barcoding in soil animal studies both strongly emphasizes the measure of the taxonomic deficit, evidencing a huge and challenging knowledge gap, and comes as a solution to address it. Becoming more and more accessible, DNA data are expected to support soil biologists in species identifications, stimulate accurate soil biodiversity surveys or any ecological research based on species lists, and help soil systematists to solve taxonomic as well as phylogenetic problems. The benefits of adopting such methods are immediate and the statement stressing that "now is the time" concurs with Janzen (2004). DNA barcoding campaigns are already running, some of them global and directly addressing soil animals; soil zoologists - taxonomists in particular - are urged to join efforts, benefiting from these new data and contributing to build the reference libraries necessary to document soil biodiversity. While facilitating and accelerating the reduction of the taxonomic impediment in a number of groups, the first benefits that would be gained are the repeatability and refutability of studies through objective assessment of the identity of the organisms studied, at last providing the long-claimed "taxonomic affidavit" (Por, 2007) toward reducing the "species uncertainty" (Hey et al., 2003) in soil sciences. Whereas priority should be given to develop taxonomy itself for groups suffering the most of that taxonomic impediment, the community of soil biologists is urged to systematically preserve vouchers of their study material to make them accessible for further study; these vouchers should ideally be preserved in a DNA-friendly way in order to allow the use of genetic methods for species identification, phylogeography, etc. Misidentifications will then be traceable, and error cascades could be stopped and tracked back after discovery of the original error. The need for expert taxonomists is overwhelming in most groups of soil animals, but placing the role of taxonomists as a central feature of ongoing and future DNA barcoding projects - as for instance in the rapidly developing earthworm and collembolan campaigns will eventually benefit the community of taxonomists. This will help in raising funds, in attracting students and developing training, thus ensuring the legacy of expertise. Nevertheless, given the extent of the taxonomic impediment, it is likely that soil biologists at large will have to embrace, at least temporarily for a number of taxa, the use of MOTUs (Blaxter, 2004; Blaxter et al., 2005); see for instance the use of genetic data as proxy for phylogenetic diversity (PD) estimations (Faith, 2008). Though not ideal, this system has no alternative if to address these groups with a huge taxonomic deficit. In nematodes for instance, 26,000 species have been described, but estimates of actual diversity range from 40,000 to 100 million species (Blaxter et al., 1998; Blaxter, 2004). Also, by being developed as collaborative and decentralized efforts involving expert taxonomists all over the world, the DNA barcoding campaigns can contribute in redistributing wealth from developed countries, where most of the funding currently originates, to developing countries, where most of the species live and where most of the zoologists need to be trained and employed. The anticipated rapid progress and enhancement of biodiversity exploration and description will offer the opportunity to develop in-depth knowledge in a much wider range of taxa, possibly demonstrating the generality of ecological theories and patterns, increasing the probability to discover novelties or to reassess some previously erroneously or incompletely addressed questions (Wilson et al., 2007). The cost-effectiveness of biodiversity surveys for soil animals will be greatly 
improved (Janzen et al., 2005; Smith et al., 2006, 2008; Gardner et al., 2008). With little doubt, by coupling DNA barcoding and their research, soil biologists will strongly reduce the effect of the taxonomic impediment and will start transcending the last frontier of soil zoology.

\section{Conclusions}

1. The observed pattern of DNA barcode variation is very favorable to the use of this marker as a species identification and discrimination tag.

2. Both collembolans and earthworms share a strong taxonomic impediment characterized both by a high level of cryptic diversity within already known species, and by a high proportion of taxa currently undescribed or needing further taxonomic scrutiny to be correctly identified.

3. DNA barcoding strongly emphasizes the taxonomic deficit in collembolans and earthworms, and comes as a promising solution to address it.

4. Adopting DNA barcoding enhances the accuracy of scientific studies and more generally benefits the community of soil biologists.

\section{Acknowledgements}

To M. Alex Smith, for his useful comments and corrections on this manuscript; to NSERC, Genome Canada and the Ontario Genomics Institute, for the financial support; to the US National Science Foundation award, for the DEB-0516439 support.

\section{References}

AGNARSSON, I.; KUNTNER, M. Taxonomy in a changing world: seeking solutions for a science in crisis. Systematic Biology, v.56, p.531-539, 2007.

ANDELMAN, S.J.;FAGAN, W.F. Umbrellas and flagships: efficient conservation surrogates or expensive mistakes? Proceedings of the National Academy of Sciences of the United States of America, v.97, p.5954-5959, 2000.

ANDRÉ, H.M.; NOTI, M.I.; LEBRUN, P. The soil fauna: the other last biotic frontier. Biodiversity and Conservation, v.3, p.45-56, 1994.

ANDRÉ, H.M; DUCARME, X.; ANDERSON, J.; CROSSLEY JUNIOR, D.; KOEHLER, H.; PAOLETTI, M.; WALTER, D.; LEBRUN, P. Skilled eyes are needed to go on studying the richness of the soil. Nature, v.409, p.761-761, 2001.

BARCODE OF LIFE DATA SYSTEMS. Advancing species identification and discovery through the analysis of short, standardized gene regions. Available at: < http://www. barcodinglife.org >. Accessed on: 25 Sept. 2009.

BHADURY, P.; AUSTEN, M.C.; BILTON, D.T.; LAMBSHEAD, P.J.D.; ROGERS, A.D.; SMERDON, G.R. Development and evaluation of a DNA-barcoding approach for the rapid identification of nematodes. Marine Ecology Progress Series, v.320, p.1-9, 2006.

BLAXTER, M.L. The promise of a DNA taxonomy. Philosophical Transactions of the Royal Society B: Biological Sciences, v.359, p.669-679, 2004.

BLAXTER, M.L.; DE LEY, P.; GAREY, J.R.; LIU, L.X.; SCHELDEMAN, P.; VIERSTRAETE, A.; VANFLETEREN, J.R.; MACKEY, L.Y;; DORRIS, M.; FRISSE, L.M.; VIDA, J.T.; THOMAS, W.K. A molecular evolutionary framework for the phylum Nematoda. Nature, v.392, p.71-75, 1998.

BLAXTER, M.L.; MANN, J.; CHAPMAN, T.; THOMAS, F.; WHITTON, C.; FLOYD, R.; ABEBE, E. Defining operational taxonomic units using DNA barcode data. Philosophical Transactions of the Royal Society of London B: Biological Sciences, v.360, p.1935-1943, 2005.

BORISENKO, A.V.; LIM, B.K.; IVANOVA, N.V.; HANNER, R.H.; HEBERT, P.D.N. DNA barcoding in surveys of small mammal communities: a field study in Suriname. Molecular Ecology Resources, v.8, 471-479, 2007.

BORTOLUS, A. Error cascades in the biological sciences: the unwanted consequences of using bad taxonomy in ecology. Ambio, v.37, p.114-118, 2008.

BROWN, J.H.; LOMOLINO, M.V. Biogeography. $2^{\text {nd }}$ ed. Sunderland: Sinauer Associates, 1998. 692p.

BURKHARDT, U.; FILSER, J. Molecular evidence for a fourth species within the Isotoma viridis group (insecta, collembola). Zoologica Scripta, v.34, p.177-185, 2005.

BURNS, J.M.; JANZEN, D.H.; HAJIBABAEI, M.; HALLWACHS, W.; HEBERT, P.D.N. DNA barcodes and cryptic species of skipper butterflies in the genus Perichares in Area de Conservacion Guanacaste, Costa Rica. Proceedings of the National Academy of Sciences, v.105, p.6350-6355, 2008.

CAMERON, E.K.; BAYNE, E.M.; COLTMAN, D.W. Genetic structure of invasive earthworms Dendrobaena octaedra in the boreal forest of Alberta: insights into introduction mechanisms. Molecular Ecology, v.17, p.1189-1197, 2008.

CAMERON, S.; RUBINOFF, D.; WILL, K. Who will actually use DNA barcoding and what will it cost? Systematic Biology, v.55, p.844-847, 2006.

CARAPELLI, A.; FANCIULLI, P.P.; FRATI, F.; DALLAI, R. The use of genetic markers for the diagnosis of sibling species in the genus Isotomurus (Insecta, Collembola). Bolletino di Zoologia, v.62, p.71-76, 1995.

CARAPELLI, A.; FRATI, F.; FANCIULLI, P.P.; NARDI, F.; DALLAI, R. Assessing species boundaries and evolutionary relationships in a group of south-western European species of Isotomurus (Collembola, Isotomidae) using allozyme data. Zoologica Scripta, v.34, p.71-79, 2005. 
CHANG, C.H.; CHEN, J.H. Taxonomic status and intraspecific phylogeography of two sibling species of Metaphire (Oligochaeta: Megascolecidae) in Taiwan. Pedobiologia, v.49, p.591-600, 2005.

CHANG, C.H.; LIN, Y.H.; CHEN, I.H.; CHUANG, S.C.; CHEN, J.H. Taxonomic re-evaluation of the Taiwanese montane earthworm Amynthas wulinensis Tsai, Shen \& Tsai, 2001 (Oligochaeta: Megascolecidae): Polytypic species or species complex? Organisms Diversity \& Evolution, v.7, p.231-240, 2007.

CHANG, C.H.; ROUGERIE, R.; CHEN, J.H. Identifying earthworms through DNA barcodes: pitfalls and promise. Pedobiologia, v.52, p.171-180, 2009.

CLARE, E.L.; LIM, B.K.; ENGSTROM, M.D.; EGER, J.L.; HEBERT, P.D.N. DNA barcoding of neotropical bats: species identification and discovery within Guyana. Molecular Ecology Notes, v.7, p.184-190, 2007.

DALEBOUT, M.L.; BAKER, C.S.; STEEL, D.; ROBERTSON, K.M.; CHIVERS, S.J.; PERRIN, W.F.; MEAD, J.G.; GRACE, R.V.; DAVID SCHOFIELD, T. A divergent mtDNA lineage among Mesoplodon beaked whales: molecular evidence for a new species in the tropical Pacific? Marine Mammal Science, v.23, p.954-966, 2007.

DANCE, A. Soil ecology: what lies beneath. Nature, v.455, p.724-725, 2008.

DECAËNS, T.; JIMÉNEZ, J.J.; GIOIA, C.; MEASEY, G.J.; LAVELLE, $P$. The values of soil animals for conservation biology. European Journal of Soil Biology, v.42, p.23-38, 2006.

DECAËNS, T.; LAVELLE, P.; JIMÉNEZ，J.J. Priorities for conservation of soil animals. CAB Reviews, v.3, p.1-18, 2008.

DECAËNS, T.; ROUGERIE, R. Description of two new species of Hemileucinae (Lepidoptera: Saturniidae) from the region of Muzo in Colombia - evidence from morphology and DNA barcodes. Zootaxa, v.1944, p.34-52, 2008.

DOMÍNGUEZ, J.; VELANDO, A.; FERREIRO, A. Are Eisenia fetida (Savigny, 1826) and Eisenia andrei Bouche (1972) (Oligochaeta, Lumbricidae) different biological species? Pedobiologia, v.49, p.81-87, 2005.

ELIAS, M.; HILL, R.I.; WILLMOTT, K.R.; DASMAHAPATRA, K.K.; BROWER, A.V.Z.; MALLET, J.; JIGGINS, C.D. Limited performance of DNA barcoding in a diverse community of tropical butterflies. Proceedings of the Royal Society B, v.274, p.2881-2889, 2007.

FAITH, D.P Phylogenetic diversity and conservation. In: CARROLL, S.P.; FOX, C. (Ed.). Conservation biology: evolution in action. New York: Oxford University, 2008. p.99-115.

FISHER, B.L.; SMITH, M.A. A revision of Malagasy species of Anochetus Mayr and Odontomachus Latreille (Hymenoptera: Formicidae). PloS ONE, v.3, e1787, 2008. Doi: 10.1371/journal. pone.0001787.

FOLMER, O.; BLACK, M.; HOEH, W.; LUTZ, R.; VRIJENHOEK, R. DNA primers for amplification of mitochondrial cytochrome $c$ oxidase subunit I from diverse metazoan invertebrates. Molecular Marine Biology and Biotechnology, v.3, p.294-299, 1994.

FRATI, F.; DELL'AMPIO, E.; CASASANTA, S.; CARAPELLI, A.; PAOLO FANCIULLI, P. Large amounts of genetic divergence among Italian species of the genus Orchesella (Insecta, Collembola) and the relationships of two new species. Molecular Phylogenetics and Evolution, v.17, p.456-461, 2000.

FULTHORPE, R.R.; ROESCH, L.F.W.; RIVA, A.; TRIPLETT, E.W. Distantly sampled soils carry few species in common. The ISME Journal, v.2, p.901-910, 2008.

GARDNER, T.A.; BARLOW, J.; ARAUJO, I.S.; ÁVILA-PIRES, T.C.; BONALDO, A.B.; COSTA, J.E.; ESPOSITO, M.C.; FERREIRA, L.V.; HAWES, J.; HERNANDEZ, M.I.M.; HOOGMOED, M.S.; LEITE, R.N.; LO-MAN-HUNG, N.F.; MALCOLM, J.R.; MARTINS, M.B.; MESTRE, L.A.M.; MIRANDA-SANTOS, R.; OVERAL, W.L.; PARRY, L.; PETERS, S.L.; RIBEIRO-JUNIOR, M.A.; SILVA, M.N.F. da; MOTTA, C. da S.; PERES, C.A. The cost-effectiveness of biodiversity surveys in tropical forests. Ecology Letters, v.11, p.139-150, 2008.

GLOBAL TAXONOMY INITIATIVE. Global Taxonomy Initiative [home page]. Available at: http://www.cbd.int/gti/ problem.shtml. Accessed on: 22 Sept. 2009.

GODFRAY, H.C.J. Challenges for taxonomy. Nature, v.417, p.17-19, 2002.

HAJIBABAEI, M.; DEWAARD, J.R.; IVANOVA, N.V.; RATNASINGHAM, S.; DOOH, R.T.; KIRK, S.L.; MACKIE, P.; HEBERT, P.D.N. Critical factors for assembling a high volume of DNA barcodes. Philosophical Transactions of the Royal Society B: Biological Sciences, v.360, p.1959-1967, 2005.

HAJIBABAEI, M.; SMITH, M.A.; JANZEN, D.H.; RODRIGUEZ, J.J.; WHITFIELD, J.; HEBERT, P.D.N. A minimalist barcode can identify a specimen whose DNA is degraded. Molecular Ecology Notes, v.6, p.959-964, 2006.

HALL, T.A. BioEdit: a user-friendly biological sequence alignment editor and analysis program for Windows 95/98/NT. Nucleic Acids Symposium Series, v.41, p.95-98, 1999.

HEBERT, P.D.N.; CYWINSKA, A.; BALL, S.L.; DEWAARD, J.R. Biological identifications through DNA barcodes. Proceedings of the Royal Society of London Series B: Biological Sciences, v.270, p.313-321, 2003.

HEBERT, P.D.N.; STOECKLE, M.Y.; ZEMLAK, T.S.; FRANCIS, C.M. Identification of birds through DNA barcodes. PLoS Biology, v.2, p.1657-1663, 2004.

HEETHOFF, M.; DOMES, K.; LAUMANN, M.; MARAUN, M.; MARAUN, M.; NORTON, R.A.; SCHEU, S. High genetic divergences indicate ancient separation of parthenogenetic lineages of the oribatid mite Platynothrus peltifer (Acari, Oribatida). Journal of Evolutionary Biology, v.20, p.392-402, 2007.

HEETHOFF, M.; ETZOLD, K.; SCHEU, S. Mitochondrial COII sequences indicate that the parthenogenetic earthworm Octolasion tyrtaeum (Savigny 1826) constitutes of two lineages differing in body size and genotype. Pedobiologia, v.48, p.9-13, 2004.

HERNIOU, E.A.; PEARCE, A.C.; LITTLEWOOD, D.T.J. Vintage helminths yield valuable molecules. Parasitology Today, v.14, p.289-292, 1998.

HEY, J.; WAPLES, R.S.; ARNOLD, M.L.; BUTLIN, R.K.; HARRISON, R.G. Understanding and confronting species 
uncertainty in biology and conservation. Trends in Ecology \& Evolution, v.18, p.597-603, 2003.

HOGG, I.D.; HEBERT, P.D.N. Biological identification of springtails (Hexapoda: Collembola) from the Canadian Arctic, using mitochondrial DNA barcodes. Canadian Journal of Zoology, v.82, p.749-754, 2004.

HOPKINS, G.W.; FRECKLETON, R.P. Declines in the numbers of amateur and professional taxonomists: implications for conservation. Animal Conservation, v.5, p.245-249, 2002.

HUANG, J.; XU, Q.; SUN, Z.J.; TANG, G.L.; SU, Z.Y. Identifying earthworms through DNA barcodes. Pedobiologia, v.51, p.301-309, 2007.

INTERNATIONAL COMMISSION ON ZOOLOGICAL NOMENCLATURE. Proposed amendment of the International Code of Zoological Nomenclature to expand and refine methods of publication. Zootaxa, v.1908, p.57-67, 2008.

IVANOVA, N.V.; DEWAARD, J.R.; HEBERT, P.D.N. An inexpensive, automation-friendly protocol for recovering high-quality DNA. Molecular Ecology Notes, v.6, p.998-1002, 2006.

JAENIKE, J. "Eisenia foetida" is two biological species. Megadrilogica, v.4, p.6-8, 1982.

JANZEN, D.H. Now is the time. Philosophical Transactions of the Royal Society B: Biological Sciences, v.359, p.731-732, 2004.

JANZEN, D.H.; HAJIBABAEI, M.; BURNS, J.M.; HALLWACHS, W.; REMIGIO, E.; HEBERT, P.D.N. Wedding biodiversity inventory of a large and complex Lepidoptera fauna with DNA barcoding. Philosophical Transactions of the Royal Society B: Biological Sciences, v.360, p.1835-1845, 2005.

KING, R.A.; TIBBLE, A.L.; SYMONDSON, W.O.C. Opening a can of worms: unprecedented sympatric cryptic diversity within British lumbricid earthworms. Molecular Ecology, v.17, p.4684-4698, 2008 .

KRELL, F.T. Parataxonomy vs. taxonomy in biodiversity studies pitfalls and applicability of 'morphospecies' sorting. Biodiversity and Conservation, v.13, p.795-812, 2004.

LARSON, B.M.H. DNA barcoding: the social frontier. Frontiers in Ecology and the Environment, v.5, p.437-442, 2007.

LOWE, C.N.; BUTT, K.R. Allolobophora chlorotica (Savigny, 1826): evidence for classification as two separate species. Pedobiologia, v.52, p.81-84, 2008.

MANDELIK,Y.;DAYAN,T.;CHIKATUNOV,V.;KRAVCHENKO, $\mathrm{V}$. Reliability of a higher-taxon approach to richness, rarity, and composition assessments at the local scale. Conservation Biology, v.21, p.1506-1515, 2007

MCNEELY, J.A. Systems or species? Approaches to conservation for the 21st century. Integrative Zoology, v.1, p.86-95, 2006.

MEIER, R.; SHIYANG, K.; VAIDYA, G.; NG, P.K.L. DNA barcoding and taxonomy of Diptera: a tale of high intraspecific variability and low identification success. Systematic Biology, v.55, p.715-728, 2006.

PEREZ-LOSADA, M.; EIROA, J.; MATO, S.; DOMINGUEZ, J. Phylogenetic species delimitation of the earthworms Eisenia fetida (Savigny, 1826) and Eisenia andrei Bouché, 1972 (Oligochaeta,
Lumbricidae) based on mitochondrial and nuclear DNA sequences. Pedobiologia, v.49, p.317-324, 2005.

POP, A.A.; WINK, M.; POP, V.V. Use of $18 \mathrm{~s}, 16 \mathrm{~s}$ rDNA and Cytochrome c Oxidase sequences in earthworm taxonomy (Oligochaeta, Lumbricidae). Pedobiologia, v.47, p.428-433, 2003.

POR, F.D. A "taxonomic affidavit": why it is needed? Integrative Zoology, v.2, p.57-59, 2007.

RATNASINGHAM, S.; HEBERT, P.D.N. BOLD: the barcode of life data system (http://www.barcodinglife.org). Molecular Ecology Notes, v.7, p.355-364, 2007.

RICHARD, B. Evaluation de la diversité spécifique des vers de terre de Haute Normandie par l'utilisation des codes barres ADN. 2008. 50p. Thesis (Master) - Université de Lyon, Lyon.

ROESCH, L.F.W.; FULTHORPE, R.R.; RIVA, A.; CASELLA, G.; HADWIN, A.K.M.; KENT, A.D.; DAROUB, S.H.; CAMARGO, F.A.O.; FARMERIE, W.G.; TRIPLETT, E.W. Pyrosequencing enumerates and contrasts soil microbial diversity. The ISME Journal, v.1, p.283-290, 2007.

ROWLEY, D.L.; CODDINGTON, J.A.; GATES, M.W.; NORRBOM, A.L.; OCHOA, R.A.; VANDENBERG, N.J.; GREENSTONE, M.H. Vouchering DNA-barcoded specimens: test of a nondestructive extraction protocol for terrestrial arthropods. Molecular Ecology Notes, v.7, p.915-924, 2007.

RUBINOFF, D.; HOLLAND, B.S. Between two extremes: mitochondrial DNA is neither the panacea nor the nemesis of phylogenetic and taxonomic inference. Systematic Biology, v.54, p.952-961, 2005.

SAMPER, C. Taxonomy and environmental policy. Philosophical Transactions of the Royal Society B: Biological Sciences, v.359, p.721-728, 2004.

SCHEFFER, S.J. Molecular evidence of cryptic species within the Liriomyza huidobrensis (Diptera: Agromyzidae). Journal of Economic Entomology, v.93, p.1146-1151, 2000.

SKAGE, M.; SCHANDER, C. DNA from formalin-fixed tissue: extraction or repair? That is the question. Marine Biology Research, v.3, p.289-295, 2007.

SMITH, M.A.; RODRIGUEZ, J.J.; WHITFIELD, J.B.; DEANS, A.R.; JANZEN, D.H.; HALLWACHS, W.; HEBERT, P.D.N. Extreme diversity of tropical parasitoid wasps exposed by iterative integration of natural history, DNA barcoding, morphology, and collections. Proceedings of the National Academy of Sciences of the United States of America, v.105, p.12359-12364, 2008.

SMITH, M.A.; WOODLEY, N.E.; JANZEN, D.H.; HALLWACHS, W.; HEBERT, P.D. DNA barcodes reveal cryptic host-specificity within the presumed polyphagous members of a genus of parasitoid flies (Diptera: Tachinidae). Proceedings of the National Academy of Sciences of the United States of America, v.103, p.3657-3662, 2006.

SONG, H.; BUHAY, J.E.; WHITING, M.F.; CRANDALL, K.A. Many species in one: DNA barcoding overestimates the number of species when nuclear mitochondrial pseudogenes are coamplified. Proceedings of the National Academy of Sciences of the United States of America, v.105, p.13486-13491, 2008. 
STORK, N.E.; GRIMBACHER, P.S.; STOREY, R.; OBERPRIELER, R.G.; REID, C.; SLIPINSKI, S.A. What determines whether a species of insect is described? Evidence from a study of tropical forest beetles. Insect Conservation and Diversity, v.1, p.114-119, 2008.

TAMURA, K.; DUDLEY, J.; NEI, M.; KUMAR, S. MEGA4: molecular evolutionary genetics analysis (MEGA) software version 4.0. Molecular Biology and Evolution, v.24, p.1596-1599, 2007.

TREWICK, S.A. DNA barcoding is not enough: mismatch of taxonomy and genealogy in New Zealand grasshoppers (Orthoptera: Acrididae). Cladistics, v.24, p.240-254, 2008.

VAGLIA, T.; HAXAIRE, J.; KITCHING, I.J.; MEUSNIER, I.; ROUGERIE, R. Morphology and DNA barcoding reveal three cryptic species within the Xylophanes neoptolemus and loelia species-groups (Lepidoptera: Sphingidae). Zootaxa, v.1923, p.18-36, 2008.

WEBB, J.M.; SUN, L.; MCCAFFERTY, W.P.; FERRIS, V.R. A new species and new synonym in Heptagenia Walsh (Ephemeroptera: Heptageniidae: Heptageniinae) based on molecular and morphological evidence. Journal of Insect Science, v.7, p.1-16, 2007.

WHEELER, Q.D. Taxonomic triage and the poverty of phylogeny. Philosophical Transactions of the Royal Society B: Biological Sciences, v.359, p.571-583, 2004.

WHEELER, Q.D.; RAVEN, P.H.; WILSON, E.O. Taxonomy: impediment or expedient? Science, v.303, p.285, 2004.
WIEMERS, M.; FIEDLER, K. Does the DNA barcoding gap exist? A case study in blue butterflies (Lepidoptera: Lycaenidae). Frontiers in Zoology, v.4, p.8, 2007.

WILL, K.W.; MISHLER, B.D.; WHEELER, Q.D. The perils of DNA barcoding and the need for integrative taxonomy. Systematic Biology, v.54, p.844-851, 2005.

WILL, K.W.; RUBINOFF, D. Myth of the molecule: DNA barcodes for species cannot replace morphology for identification and classification. Cladistics, v.20, p.47-55, 2004.

WILSON, E.O. Taxonomy as a fundamental discipline. Philosophical Transactions of the Royal Society B: Biological Sciences, v.359, p.739, 2004.

WILSON, E.O. The encyclopedia of life. Trends in Ecology \& Evolution, v.18, p.77-80, 2003.

WILSON, J.R.U.; PROCHES, S.; BRASCHLER, B.; DIXON, E.S.; RICHARDSON, D.M. The (bio)diversity of science reflects the interests of society. Frontiers in Ecology and the Environment, v.5, p.409-414, 2007.

ZHOU, X.; KJER, K.M.; MORSE, J.C. Associating larvae and adults of Chinese Hydropsychidae caddisflies (Insecta: Trichoptera) using DNA sequences. Journal of the North American Benthological Society, v.26, p.719-742, 2007.

ZIMMERMANN, J.; HAJIBABAEI, M.; BLACKBURN, D.C.; HANKEN, J.; CANTIN, E.; POSFAI, J.; EVANS JUNIOR, T.C. DNA damage in preserved specimens and tissue samples: a molecular assessment. Frontiers in Zoology, v.5, 2008. Doi: 10.1186/1742-9994-5-18. 